\title{
From ISET to InDRE. V. Institute of Epidemiological Diagnosis and Reference. Global strategic position, 2012-2019
}

José A. Díaz-Quiñonez ${ }^{*}$ Jorge A. Ramírez-Hernández, ${ }^{1}$ Martha E. Rodríguez-Pérez, ${ }^{2}$

Carlos Viesca-Treviño ${ }^{1}$ and Carmen Guzmán-Bracho ${ }^{3}$

'Universidad Nacional Autónoma de México, Faculty of Medicine, Postgraduate Education Division; '2Universidad Nacional Autónoma de México, Faculty of Medicine, Department of History and Philisophy of Medicine; ${ }^{3}$ Institute of Epidemiological Diagnosis and Reference.Mexico City, Mexico

\begin{abstract}
This document describes the changes at the Institute of Epidemiological Diagnosis and Reference (InDRE) from 2012 to 2019, the administrative and equipment modifications, the new headquarters and the National System of Epidemiological Surveillance legal modifications. The process of relocation is mentioned, especially the careful transfer of the biological material protected by the Institute, and the new way of studying epidemic outbreaks, endemic diseases and the negative network is analyzed. At the international level, the promotion of links with global networks of the Pan American Health Organization, the World Health Organization (WHO) and other international organizations is described. The assignation to InDRE of four WHO collaborating centres is also mentioned. The Global Health Security Initiative Laboratory Network acknowledged InDRE's leadership, which co-chaired the working group during the study period.
\end{abstract}

KEY WORDS: Institute of Epidemiological Diagnosis and Reference. History of medicine. Public health.

\section{Del ISET al InDRE. V. Instituto de Diagnóstico y Referencia Epidemiológicos. Posición estratégica global, 2012-2019}

\section{Resumen}

En este documento se describen los cambios en el Instituto de Diagnóstico y Referencia Epidemiológicos (InDRE) de 2012 a 2019, las modificaciones administrativas y de equipamiento, la nueva sede y las modificaciones jurídicas al Sistema Nacional de Vigilancia Epidemiológica. Se menciona el proceso de mudanza, en especial el cuidadoso traslado del material biológico que resguarda el Instituto y se analiza la nueva forma de estudiar los brotes epidémicos, los padecimientos endémicos y la red negativa. Respecto al ámbito internacional, se describe el fomento de la vinculación con redes globales de la Organización Panamericana de la Salud, la Organización Mundial de la Salud (OMS) y otros organismos internacionales. También se menciona la designación en el InDRE de cuatro centros colaboradores de la OMS. La Red de Laboratorios de la Iniciativa Global para la Seguridad en Salud reconoció el liderazgo del InDRE, cuyo director ocupó la copresidencia del grupo de trabajo en el periodo de estudio.

PALABRAS CLAVE: Instituto de Diagnóstico y Referencia Epidemiológicos. Historia de la medicina. Salud pública.

Correspondence:

*José A. Díaz-Quiñonez

E-mail: adiazq@unam.mx
Gac Med Mex. 2020;156:236-245

Contents available at PubMed

www.gacetamedicademexico.com

0016-3813/@ 2020 Academia Nacional de Medicina de México, A.C.. Published by Permanyer. This is an open access article under the CC BY-NC-ND license (http://creativecommons.org/licenses/by-nc-nd/4.0/). 
... that which on the tree is flowering, lives from that which it has buried in the ground. Francisco LUIS BERNÁRDEZ

\section{Introduction}

This article gives continuity to number IV of the "From ISET to InDRE" series, ${ }^{1}$ where the complex operation of the National Network of Public Health Laboratories (RNLSP - Red Nacional de Laboratorios de Salud Pública) was described.

The changes at InDRE in the 2012-2019 period had repercussions on the entire structure of the National System of Epidemiological Surveillance (SINAVE Sistema Nacional de Vigilancia Epidemiológica), which was organized according to the Official Mexican Standard NOM-017-SSA2-2012, for epidemiological surveillance (Fig. 1). On one hand, there are the National Committee of Epidemiological Surveillance, the General Directorate of Epidemiology, InDRE and the epidemiological surveillance units; and, on the other, the flows of information and samples, whose entrance door are the epidemiological surveillance units of all institutions of the health sector. ${ }^{2}$ The entire process is regulated by the National Committee of Epidemiological Surveillance and the General Directorate of Epidemiology. When SINAVE requires confirmation of cases, RNLSP and InDRE are incorporated. ${ }^{1}$

In 2013, InDRE changed its headquarters, although preparations had started since the previous year. It took three months for the institution's teams and working groups stepwise mobilization. On April 7, 2014, the new facilities were formally opened.

\section{Regarding the change of institutional headquarters}

\section{Administrative and work modifications}

As part of the strategy for the management of the change towards the modernization and systematization of InDRE's attributions, the Quality Management System was implemented in 2012, with a focus on processes and a risk-based approach. The incorporation of the biological risk management standard for laboratories, the CWA15793:2011 standard, consolidated the Institute's comprehensive management model, so far the only one in the world for national reference laboratories.

The imminence of the change of institutional headquarters generated more commitment and a sense of belonging among the personnel and, at the same time, uncertainty and concern. By means of tripartite dialogue tables, with the participation of workers, union and institutional authorities, adapting the profiles of the positions in the job profile diagram was agreed, the staff members who were under contract were workwise institutionalized and the change of assignment of 59 workers (who represented around $10 \%$ of the workforce) was allowed. ${ }^{3}$ At the same time, 67 newly-created positions were obtained, which triggered more than a hundred hierarchical movements.

\section{Legal modifications}

In 2013, the Official Mexican Standard NOM-017SSA2-2012, for epidemiological surveillance, was updated, ${ }^{2}$ with InDRE acquiring legal support as a national reference laboratory. The previous year, the Institute had joined the General Directorate of Epidemiology, in accordance with the new Internal Regulations of the Ministry of Health. ${ }^{4}$ The NOM-017-SSA2-2012 standard established the protocols to update InDRE's operational criteria and technical guidelines. These documents have incorporated new methodological developments in the diagnostic algorithms and express RNLSP technological innovation. ${ }^{5}$

Also in 2013, owing to its "high national importance", the new property was designated as a triple A strategic facility, in terms of the General Statute of the National System of Public Security, and as a National Security Agency, in accordance with the collaboration bases signed between the Ministry of Health and the Ministry of the Interior. ${ }^{6}$

\section{Relocation}

During the relocation process, InDRE had to retain the capacity to carry out "critical" diagnostic algorithms and continue operating should any epidemiological contingency occur in the country. Activities were maintained at the Santo Tomás facilities and the RNLSP members supported while all the diagnostic phases were transferred to the new headquarters. Technical and administrative processes were carefully planned and executed, including the chain of custody and biosafety.

The most important challenge in the relocation process was the transfer of the biological material stored in the Institute's facilities. It was a national security event in terms of biological risk management. ${ }^{7}$ 


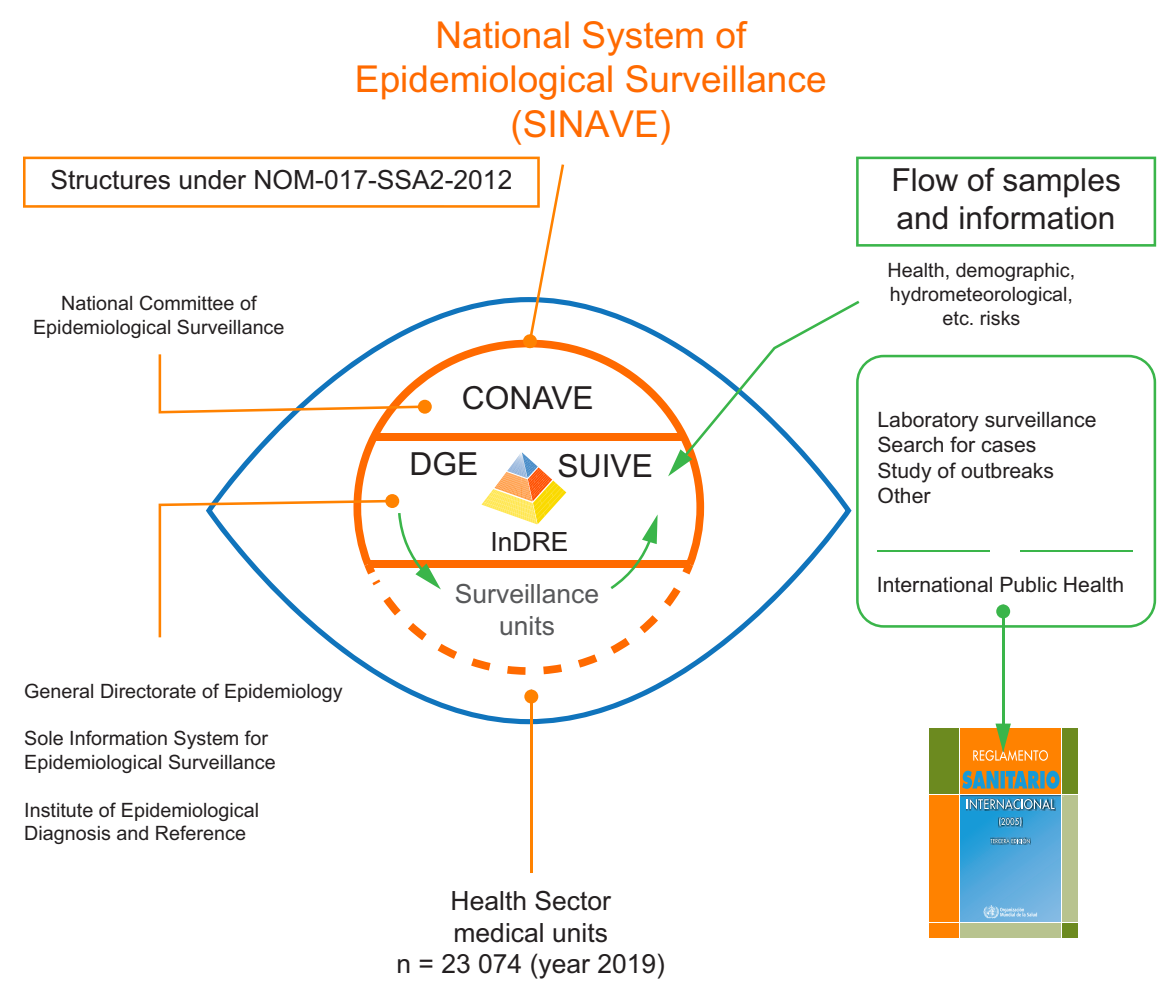

Figure 1. Diagram of the National System of Epidemiological Surveillance, where the role of the national reference laboratory (InDRE) is shown. Mexico, 2019.

After performing an exhaustive inventory of the biological material that had to be transported from the old facilities to the new ones, the Pan American Health Organization/World Health Organization (PAHO/ WHO) regional office was informed. Hours before the transfer, InDRE staff packed the material, in accordance with international criteria. The transfer of all the material was carried out on Saturday, November 16, 2013, around midnight, in a single trip, with a caravan of trucks escorted by members of the Federal Police.

Due to its relevance, the operation was planned and coordinated by CISEN officials (Center for Investigation and National Security, now the National Intelligence Center) and the InDRE, with participation of members of the legal cabinet staff: Ministry of the Interior, Ministry of National Defense, Ministry of Communications and Transportation, in addition to the Federal Police. The High Level Specialized Committee on Disarmament, Terrorism and International Security Matters coordinated the compliance with international agreements on the subject. The WHO shipping pass was signed at the former facilities, and the mobilization process was notified to $\mathrm{PAHO} / \mathrm{WHO}$, the United
Nations Office for Disarmament Affairs and the Biological Weapons Convention.

Work continued until dawn for InDRE staff. As the areas were vacated and the laboratories, laboratory animal facilities, insectariums, cold rooms, etc. were dismantled, bio-decontamination and disinfection (environmental biosafety) was carried out to ensure the safety of the furniture, materials, equipment and buildings at the time the old property was delivered.

After having been settled for 78 years in the Santo Tomás neighborhood, InDRE moved to the new property that had belonged to the grounds of an old hacienda, then to La Castañeda General Insane Asylum (1910-1968) and to the National Institute of Human Communication (1968-2002). ${ }^{8}$

\section{Opening}

Finally, on April 7, 2014, the World Health Day, that year dedicated to vector-borne diseases, the official opening ceremony of the new facilities was celebrated in presence of the President of the Republic, Enrique Peña Nieto; the Secretary of Health, Mercedes Juan López; and the representative of the PAHO/WHO 
Table 1. National Network of Public Health Laboratories. Integration of specific laboratory networks. $2019^{5}$

\begin{tabular}{|c|c|c|c|c|}
\hline \multicolumn{2}{|c|}{ Network } & \multirow{2}{*}{$\begin{array}{l}\text { Public health state } \\
\text { laboratories } \\
32\end{array}$} & \multirow{2}{*}{$\begin{array}{l}\text { Laboratories of epidemiological } \\
\text { surveillance support (LAVE)* } \\
-\end{array}$} & \multirow{2}{*}{$\begin{array}{c}\begin{array}{c}\text { Jurisdictional/local } \\
\text { laboratories }\end{array} \\
116\end{array}$} \\
\hline 1 & Malaria & & & \\
\hline 2 & Influenza and other respiratory viruses & 32 & 8 & - \\
\hline 3 & Tuberculosis & 31 & - & 737 \\
\hline 4 & Dengue and other arboviroses & 31 & 1 & 3 \\
\hline 5 & Acute bacterial diarrheic disease & 31 & 1 & - \\
\hline 6 & Febrile exanthematous illness & 31 & 1 & - \\
\hline 7 & Brucellosis & 31 & - & - \\
\hline 8 & Sexually-transmitted infections & 31 & - & - \\
\hline 9 & Hepatitis & 30 & - & - \\
\hline 10 & HV-AIDS & 30 & - & - \\
\hline 11 & Chagas disease & 29 & - & - \\
\hline 12 & Acute bacterial respiratory infections & 28 & - & - \\
\hline 13 & Pertussis & 28 & - & - \\
\hline 14 & Leishmaniasis & 28 & - & 116 \\
\hline 15 & Rotavirus and other enteroviruses & 27 & - & - \\
\hline 16 & Entomology & 27 & - & 1 \\
\hline 17 & Rabies & 25 & - & - \\
\hline 18 & Cervical cytology & 21 & - & 74 \\
\hline 19 & Leptospira & 21 & - & - \\
\hline 20 & Rickettsiosis & 4 & - & - \\
\hline
\end{tabular}

office in Mexico, Maureen Birmingham. This event was reported in all national circulation newspapers, on eight front pages (El Universal, Reforma, Excélsior, El Sol de México, Impacto Diario, Diariolmagen, Ovaciones, Unomásuno) and on inside pages in the rest of the written press. The Secretary of referred to InDRE as follows: ${ }^{9}$

... main point of support for the national epidemiological surveillance system... (it) is part of the national security strategy to respond to highly dangerous biological emergencies.

Similar to the note "Finally, it will be founded", published in 1936 by El Universal on the occasion of the foundation of the Sanitary and Tropical Diseases Institute (ISET - Instituto de Salubridad y Enfermedades Tropicales), the newspaper Reforma, 78 years later, titled its note "Finally, InDRE's headquarters are opened".

\section{A new way to approach epidemiological surveillance}

Currently, the country has 20 specific diagnostic networks under the stewardship of InDRE as National Reference Laboratory (Table 1). In addition to the new infrastructure, practically all laboratory, computing and communication equipment was replaced. The laboratory equipment changed from monocular microscopes with external lamps to optical microscopes with LED illumination and digitized documentation; from classical bacteriology to gene sequencing; from agglutination tests, to automated chemiluminescence, to real-time quantitative PCR, to next-generation sequencing, and to bioinformatics. Together, these transformations constitute the most important technological renewal of the Institute since its foundation. 
As a result, there were modifications in the Institute's participation in epidemiological surveillance. Below, some aspects are described.

\section{Epidemic outbreaks}

In the reviewed period, the Institute participated by characterizing epidemic outbreaks using a more expedite strategy with higher predictive value, based on the identification and analysis of nucleic acids by real-time PCR and whole-genome sequencing. A clear example of InDRE's contribution was the characterization of a highly pathogenic avian A influenza strain (H7N3) in poultry farm workers from Jalisco. ${ }^{10}$ The transmission of the chikungunya ${ }^{11}$, Zika $^{12}$, and dengue ${ }^{13}$ viruses in our country was also studied, the circulation of non-polio D68 enterovirus was identified in respiratory conditions and the diagnosis of influenza in children was ruled out at the Institute. ${ }^{14}$

Detection of the Aedes mosquito in Mexico City ${ }^{15}$ triggered focused monitoring and surveillance activities. ${ }^{16}$ As a consequence, all state public health laboratories (LESP - Laboratorios Estatales de Salud Pública) have had, since then, molecular methodologies available for these diagnoses, which facilitated national response.

During the cholera outbreak in Mexico in the 20132014 period, diagnosis was obtained with conventional methods, and with molecular methods, the origin of the strain (Haiti) that caused the re-emergence of this disease was established. With a mobile field laboratory, the time of response for the care of affected individuals was reduced, which facilitated decision-making. The outbreak was controlled by SINAVE and inter-sectoral participation in only 13 weeks. ${ }^{17}$

Given the possible introduction in Mexico of highly infectious unknown pathogens such as Ebola, and the reintroduction of others, such as the yellow fever virus, InDRE strengthened the capacity to receive them at its new facilities and to contain them in level $3 \mathrm{bi}$ ological safety laboratories; it also reinforced the communication networks with computer systems.

\section{Endemics}

The Mexican experience in malaria eradication facilitated WHO certification of all microscopists at InDRE Malaria Laboratory, which allowed the creation of the WHO Collaborating Center for Malaria. This certified personnel maintains its high level throughout the country and also carries out parasitological diagnoses for leishmaniasis and Chagas disease (Juan Manuel Serna-Velázquez, personal communication).
Chagas disease serological diagnosis is essential for strategies to control the transmission of this parasite. To that end, InDRE developed a national reference algorithm and a solid performance evaluation program where RNLSP members and the National Center for Blood Transfusion participate, to ensure diagnostic reliability.

The Tuberculosis Network started operating since the decade of 1970; currently, it has 768 laboratories of different levels of complexity throughout the country. Bacteriological tests are the basis of this network. $^{7}$

The establishment of the Rickettsiosis Epidemiological Surveillance program allowed the creation of the Institute's most recent diagnostic network.

In November 2019, the WHO granted Mexico the first certification in the world as a country free of dog-transmitted human rabies, based on scientific evidence provided by InDRE and RNLSP.

\section{Surveillance of eliminated or eradicated diseases (negative network)}

The negative network includes diseases without autochthonous cases in Mexico² (Table 2). As a relevant example, InDRE has participated in the polio eradication process, with the diagnosis of probable cases in outbreak studies and through environmental surveillance; in addition, it is the only agency that generates laboratory information for epidemiological surveillance of acute flaccid paralysis in Mexico.

\section{Recognitions, academic activity and scientific production}

The Institute received the ISO 15189:2012 accreditation, ISO 9001:2015 certification and the $2015 \mathrm{Na}-$ tional Health Quality Award. That year, InDRE was granted the Funsalud-GSK Award in the category of epidemiological research; in 2017, a recognition with the CANIFARMA Award and was a finalist in the CarIos Slim Award to the Exceptional Institution. In 2019, it was finalist for the National Quality Award granted by the Ministry of Economy.

In 2014, the National Council of Science and Technology distinguished Dr. Clara Gorodezky as emeritus researcher, and she was also named "Person of the Year 2019" at Forbes Health Forum, due to her contributions to the benefit of health. ${ }^{18}$

In the 2012-2019 period, 179 articles were published in peer-reviewed indexed journals, 2972 
Table 2. InDRE participation in the surveillance of conditions with no autochthonous cases recorded in the national territory

\begin{tabular}{l|l|l|}
\hline Condition & Year the last cases were recorded & Origin \\
\hline Polio & 1990 & Jalisco \\
\hline Diphtheria & 1991 & Michoacán \\
\hline Measles* & 1996 & Federal District \\
\hline Onchocerciasis & 1998 & Oaxaca \\
\hline Dog or cat-transmitted human rabies & 2004 & Sinaloa \\
\hline Blindness caused by trachoma & 2007 & Chiapas \\
\hline Congenital rubella syndrome* & 2008 & Nuevo León \\
\hline Malaria caused by Plasmodium falciparum* & 2009 & Sonora \\
\hline Rubella* & 2010 & Distrito Federal and Nuevo León \\
\hline Rhodnius prolixus-transmitted Chagas disease & 2012 & Chiapas \\
\hline Cholera* & 2018 & Sinaloa \\
\hline *The diagnosis is made by the entire RNLSP. & &
\end{tabular}

genetic sequences and complete genomes were deposited in public or restricted databases, and the number of members at the National System of Researchers increased by $143 \%$, due to the training and incorporation of young professionals with postgraduate degrees.

All these achievements illustrate the expertise, commitment and human talent that InDRE has developed and offered to the field of public health.

\section{InDRE international participation}

According to the WHO, among the top 10 health problems in 2019, six are related to infectious diseases: influenza as a pandemic event, antimicrobial resistance, the threat of spread of the Ebola virus and other pathogens (including $X$ disease, which represents the need for preparedness for an unknown pathogen that might cause a serious epidemic), vaccine hesitancy, dengue and human immunodeficiency virus.

In addition to intensive technical meetings, InDRE has participated in many other on national laboratory policies, planning, regulation, biological risk management, and financing. It has also maintained collaboration with global networks and has joined other new ones (Table 3). The InDRE National Influenza Center has been maintained since $1951^{19}$ and was re-designated in 2016. The InDRE Tuberculosis Laboratory has been a supranational laboratory for Central America since 2005; in 2016, it was accredited as member of the Network of Supranational Reference Laboratories for Tuberculosis by the WHO Global Tuberculosis Program. ${ }^{20,21}$

Through the United States Northern Command, in 2017, InDRE received a next-generation sequencer to decrease response times in epidemic events, such as Zika, influenza, and foodborne diseases. ${ }^{22}$

InDRE is part of the Global Health Security Initiative Laboratory Network (Table 3), where only the seven most industrialized countries and Mexico participate; ${ }^{23}$ the InDRE director was unanimously elected co-chair for the 2012-2019 period. Mexico hosted the meetings of that body in 2014 and 2017.

\section{WHO collaborating centres at InDRE}

Between 2012 and 2019, the Institute received important designations from PAHO/WHO (Table 4). A WHO Collaborating Centre (WHOCC) is an institution designated to carry out activities in support of WHO's public health programs. InDRE received four designations as WHOCC:

- WHO Collaborating Centre for Training on Malaria Microscopy Diagnosis. ${ }^{24}$

- WHO Collaborating Centre on Laboratory Biosafety. ${ }^{25}$

- WHO Collaborating Centre for Arboviruses. ${ }^{26}$

- WHO Collaborating Centre on Laboratory Quality Management. ${ }^{27}$

With these designations, $28 \%$ of the WHOCCs established in the country are under the care of InDRE. ${ }^{28}$ 
Gaceta Médica de México. 2020;156

Table 3. InDRE participation in global and multinational diagnostic networks

\begin{tabular}{|c|c|c|}
\hline Program & Coordinating body & Objective \\
\hline \multicolumn{3}{|c|}{ PAHO/WHO global networks } \\
\hline The Global Polio Laboratory Network & WHO & $\begin{array}{l}\text { To differentiate polioviruses from other causes of acute } \\
\text { flaccid paralysis }\end{array}$ \\
\hline $\begin{array}{l}\text { Global Influenza Surveillance and } \\
\text { Response System (GISRS) }\end{array}$ & WHO & $\begin{array}{l}\text { Global network for influenza epidemiology and virology } \\
\text { surveillance }\end{array}$ \\
\hline $\begin{array}{l}\text { WHO External Quality Assessment Project } \\
\text { for the detection of influenza viruses }\end{array}$ & $\begin{array}{l}\text { WHO/Centre for Health Protection, } \\
\text { (Hong Kong) }\end{array}$ & $\begin{array}{l}\text { To assure quality and improve the capacity of } \\
\text { laboratories at the global level for the detection and } \\
\text { sub-typing of the influenza virus (support to GISRS) }\end{array}$ \\
\hline $\begin{array}{l}\text { Global Measles and Rubella Laboratory } \\
\text { Network }\end{array}$ & PAHO & $\begin{array}{l}\text { To monitor and verify viral transmission and monitoring } \\
\text { the susceptibility profile of a population }\end{array}$ \\
\hline $\begin{array}{l}\text { System of Networks for the Surveillance } \\
\text { of Agents Responsible for Bacterial } \\
\text { Pneumonias and Meningitis }\end{array}$ & PAHO & $\begin{array}{l}\text { Epidemiological surveillance of bacterial pneumonias } \\
\text { and meningitis }\end{array}$ \\
\hline $\begin{array}{l}\text { Latin American Network for Antimicrobial } \\
\text { Resistance Surveillance }\end{array}$ & PAHO & $\begin{array}{l}\text { Surveillance of resistance in nosocomial and } \\
\text { community-acquired pathogens }\end{array}$ \\
\hline Pan American Cytology Network & PAHO & To improve the quality of the Papanicolaou test \\
\hline Global Salm-Surv & WHO & $\begin{array}{l}\text { To strengthen surveillance of foodborne diseases. Alert } \\
\text { and response in case of outbreaks }\end{array}$ \\
\hline Laboratory Network for Arbovirus Diagnosis & PAHO & $\begin{array}{l}\text { To strengthen diagnosis in order to ensure a timely } \\
\text { response to outbreaks and epidemics }\end{array}$ \\
\hline $\begin{array}{l}\text { Genomic Surveillance of Dengue in the } \\
\text { Americas }\end{array}$ & WHO/PAHO & $\begin{array}{l}\text { To promote genomic surveillance studies of dengue and } \\
\text { other arboviruses in the Region of the Americas }\end{array}$ \\
\hline $\begin{array}{l}\text { External Evaluation of Performance in the } \\
\text { Diagnosis of Emerging and Reemerging } \\
\text { Infectious Diseases }\end{array}$ & $\begin{array}{l}\text { PAHO/WHO/National Center of } \\
\text { Tropical Diseases (Bolivia) }\end{array}$ & $\begin{array}{l}\text { To assess the capacity of national reference laboratories } \\
\text { of the Region of the Americas }\end{array}$ \\
\hline $\begin{array}{l}\text { Program for Quality Control in Bacteriology } \\
\text { and Antimicrobial Resistance }\end{array}$ & $\begin{array}{l}\text { PAHO/National Institute of } \\
\text { Infectious Diseases (Argentina) }\end{array}$ & Quality Control Program to support ReLAVRA \\
\hline $\begin{array}{l}\text { Program for External Evaluation of } \\
\text { Performance in Malaria Microscopy } \\
\text { Diagnosis for the Countries of Mesoamerica } \\
\text { and the Caribbean }\end{array}$ & $\mathrm{PAHO}$ & $\begin{array}{l}\text { To establish the technical procedure for the } \\
\text { organization, design and evaluation of national } \\
\text { reference laboratories in the countries of the sub-region. }\end{array}$ \\
\hline $\begin{array}{l}\text { TB Supranational Reference Laboratory } \\
\text { Network }\end{array}$ & WHO & $\begin{array}{l}\text { Surveillance of Mycobacterium tuberculosis drug } \\
\text { resistance }\end{array}$ \\
\hline $\begin{array}{l}\text { Mycobacterium tuberculosis Drug } \\
\text { Susceptibility Quality Control Program }\end{array}$ & PAHONHO & $\begin{array}{l}\text { To strengthen the capacity of laboratories in the } \\
\text { countries to identify the global magnitude of } \\
\text { Mycobacterium tuberculosis resistance }\end{array}$ \\
\hline $\begin{array}{l}\text { Network for Evaluation of Vaccine } \\
\text { Effectiveness in Latin America and the } \\
\text { Caribbean. Influenza }\end{array}$ & PAHO/CDC (United States) & $\begin{array}{l}\text { To provide information on the effectiveness of the } \\
\text { seasonal influenza vaccine }\end{array}$ \\
\hline $\begin{array}{l}\text { The External Quality Assurance System } \\
\text { of the WHO Global Foodborne Infections } \\
\text { Network }\end{array}$ & $\begin{array}{l}\text { WHO/Technical University of } \\
\text { Denmark (Denmark) }\end{array}$ & $\begin{array}{l}\text { To assess the ability of Member States to detect and } \\
\text { respond to outbreaks of foodborne diseases and to the } \\
\text { emergence of antimicrobial resistance }\end{array}$ \\
\hline \multicolumn{3}{|c|}{ Multinational networks } \\
\hline $\begin{array}{l}\text { Global Health Security Action Group- } \\
\text { Laboratory Network }\end{array}$ & $\begin{array}{l}\text { Global Health Security Initiative } \\
\text { (Group of Seven + México) }\end{array}$ & $\begin{array}{l}\text { Partnership between laboratories in the countries of the } \\
\text { Group of Seven and Mexico in order to strengthen global } \\
\text { public health preparedness and response to chemical, } \\
\text { biological, radiological and nuclear terrorism threats }\end{array}$ \\
\hline & & (Continued) \\
\hline
\end{tabular}


Table 3. InDRE participation in global and multinational diagnostic networks (Continued)

\begin{tabular}{|l|l|l|l|l|l}
\hline Program & Coordinating body & Objective \\
\hline $\begin{array}{l}\text { International Proficiency Testing Scheme for } \\
\text { the Leptospirosis MAT }\end{array}$ & $\begin{array}{l}\text { International Leptospirosis Society } \\
\text { (National Serology Reference } \\
\text { Laboratory, Australia) }\end{array}$ & To improve the diagnosis of leptospirosis in the world \\
\hline Performance Evaluation Program & $\begin{array}{l}\text { Division of Laboratory Systems, } \\
\text { CDC }\end{array}$ & $\begin{array}{l}\text { To improve surveillance and public health, clinical } \\
\text { laboratory quality and safety, data science, } \\
\text { biorepositories, and working competence }\end{array}$ \\
\hline PulseNet and PulseNet-NGS & CDC & $\begin{array}{l}\text { To compare patterns of bacterial DNA obtained from } \\
\text { individuals involved in outbreaks related to food safety }\end{array}$ \\
\hline Laboratory Response Network & CDC & $\begin{array}{l}\text { Network of laboratories that can respond to biological } \\
\text { and chemical threats, as well as to other public health } \\
\text { emergencies }\end{array}$ \\
\hline Global Microbe Identifier-Proficiency Test & $\begin{array}{l}\text { Technical University of Denmark } \\
\text { (Denmark) }\end{array}$ & $\begin{array}{l}\text { To harmonize and standardize whole-genome } \\
\text { sequencing of emerging pathogens, data analysis, and } \\
\text { bioinformatics }\end{array}$ \\
\hline $\begin{array}{l}\text { United Nations Secretary-General's } \\
\text { Mechanism-Proficiency Test }\end{array}$ & $\begin{array}{l}\text { United Nations Office for } \\
\text { Disarmament Affairs/Technical } \\
\text { University of Denmark }\end{array}$ & $\begin{array}{l}\text { To strengthen the ability to detect a biological threat, } \\
\text { based on genomic and bioinformatics analysis }\end{array}$ \\
\hline
\end{tabular}

PAHO = Pan American Health Organization; WHO = World Health Organization; GISRS = Global Influenza Surveillance and Response System; ReLAVRA (Red Latinoamericana de Vigilancia de la Resistencia a los Antimicrobianos) = Latin American Network for Antimicrobial Resistance Surveillance; NGS = next-generation sequencing, CDC = Centers for Disease Control and Prevention.

\section{Discussion}

The opening of new and modern strategic facilities, the reengineering of processes, technological renewal, the creation of new positions and the associated hierarchical movements generated a favorable environment for the projection of InDRE in the 2012-2019 period. Together, these events constitute the deepest renovation of the Institute since its foundation in 1938.

In the review herein presented, three elements were considered: the lessons of ISET-InDRE historical recovery, Mexico's epidemiological challenges and the institution's forward planning.

The historical analysis showed the character traits present in the Institute since its birth:

- Multidimensional approach to health problems, considering the basic, entomological, clinical, epidemiological and humanistic aspects, to support priority health campaigns and programs of each period.

- The seriousness and robustness of scientific research carried out at the Institute, which offers answers to the most important health problems, although the complicated internal situation of the country, as well as in the borders, has posed challenges to national public health, which is inseparable of global public health.
From this significant institutional biography, we can conclude that InDRE must maintain its strong sense of identity and promote continuous and intense scientific, technological and humanistic development. With this, it will be able to help facing both infectious and chronic and non-communicable diseases.

In December 2019, in the province of Wuhan, China, an epidemic outbreak of the SARS-CoV2 coronavirus, the cause of Covid-19, was initiated, with disease quickly turning into a pandemic. In the face of this new global challenge, InDRE was the first institution in Latin America to carry out the confirmation of cases by molecular methods. The methodology would be transferred in a matter of few days to the RNLSP. ${ }^{29}$

The diagnostic task in charge of InDRE must go beyond the laboratory and include economic, social and ecological aspects in order to explain the complexity behind the morbidity and mortality figures. In the near future, InDRE should maintain the momentum in high-level research and link with clinical areas of national health institutes as well as with reference and high specialty hospitals.

Building upon its great past, InDRE should continue in the $21^{\text {st }}$ century as a national security institution, leader in global public health. 
Table 4. World Health Organization designations for InDRE, 2012 to 2019

\begin{tabular}{|c|c|c|c|}
\hline $\begin{array}{l}\text { Year of } \\
\text { designation }\end{array}$ & WHOCC name & National program it supports & International program it supports \\
\hline $2016^{*}$ & National Influenza Center & $\begin{array}{l}\text { Prevention and Control of } \\
\text { Respiratory Diseases and } \\
\text { INFLUENZA }\end{array}$ & $\begin{array}{l}\text { Global Influenza Surveillance and } \\
\text { Response System }\end{array}$ \\
\hline $2016^{* *}$ & TB Supranational Laboratory & $\begin{array}{l}\text { Prevention and Control of } \\
\text { Tuberculosis }\end{array}$ & End TB Strategy \\
\hline 2017 & $\begin{array}{l}\text { WHO Collaborating Center for Training on } \\
\text { Malaria Microscopy Diagnosis }\end{array}$ & Prevention and Control of Malaria & $\begin{array}{l}\text { Global Technical Strategy for Malaria } \\
\text { 2016-2030 }\end{array}$ \\
\hline 2017 & $\begin{array}{l}\text { WHO Collaborating Center on Laboratory } \\
\text { Biosafety }\end{array}$ & $\begin{array}{l}\text { National Network of Public Health } \\
\text { Laboratories }\end{array}$ & One World, One Health Agenda \\
\hline 2017 & WHO Collaborating Centre for Arboviruses & $\begin{array}{l}\text { Epidemiological Surveillance of } \\
\text { Vector-Transmitted Viral Diseases }\end{array}$ & $\begin{array}{l}\text { Arbovirus Diagnostic Laboratory } \\
\text { Network in the Americas }\end{array}$ \\
\hline 2018 & $\begin{array}{l}\text { WHO Collaborating Centre on Laboratory } \\
\text { Quality Management }\end{array}$ & $\begin{array}{l}\text { National Network of Public Health } \\
\text { Laboratories }\end{array}$ & $\begin{array}{l}\text { Conference on Laboratory Quality } \\
\text { Systems }\end{array}$ \\
\hline $2018^{* * *}$ & Poliovirus-Essential Facilities & $\begin{array}{l}\text { Polio and acute flaccid paralysis } \\
\text { surveillance }\end{array}$ & Global Polio Eradication Initiative \\
\hline
\end{tabular}

*First appointment in 1951; re-designation in 2016.

${ }^{* *}$ First appointment in 2005; re-designation in 2016.

${ }^{\star \star *}$ At the request of the health authority in 2018.

\section{Acknowledgements}

Our recognition to the National Network of Public Health Laboratories and to the InDRE community, which over the years have demonstrated their enormous professionalism and commitment to public health in Mexico. José A. Díaz-Quiñonez thanks the members of the Global Health Security Initiative Laboratory Network for the support provided during his tenure as co-chair (2012-2019). Our appreciation to Irma López-Martínez, Lucía Hernández-Rivas, Jean-Marc Gabastou for the interviews they kindly granted us.

\section{Funding sources}

This research has not received any specific grant from public or commercial sector agencies or non-profit entities.

\section{Conflict of interests}

None.

\section{Ethical disclosures}

Protection of people and animals. The authors declare that no experiments were performed on humans or animals for this research.
Confidentiality of data. The authors declare that no patient data appear in this article.

Right to privacy and informed consent. The authors declare that no patient data appear in this article.

\section{References}

1. Guzmán-Bracho C, Ramírez-Hernández JA, Rodríguez-Pérez ME, Viesca-Treviño C, Díaz-Quiñonez JA. Desde el ISET al InDRE. Desde el ISET al InDRE. IV. Instituto de Diagnóstico y Referencia Epidemiológicos: Nueva orientación, 1990-2012. Gac Med Mex. 2020;155:322-327.

2. Norma Oficial Mexicana NOM-017-SSA2-2012, para la vigilancia epidemiológica. México: Diario Oficial de la Federación. 2013 Feb 19.

3. Diaz-Quiñonez JA. Informe de gestión 2012-2019. En: Acta administrativa de entrega-recepción de la Dirección General Adjunta del Instituto de Diagnóstico y Referencia Epidemiológicos. México: Secretaría de la Función Pública; 2019

4. Decreto que reforma, adiciona y deroga diversas disposiciones del Reglamento Interior de la Secretaría de Salud. México: Diario Oficial de la Federación. 2018 Feb 07.

5. Lineamientos vigentes, Red Nacional de Laboratorios de Salud Pública. Colección de Publicaciones Técnicas del InDRE. México: Secretaría de Salud [sitio web]. [Actualizado 2016 Oct ${ }^{26}$. Disponible en: Https://www. gob.mx/salud/documentos/lineamientos-vigentes-red-nacional-de-laboratorios-de-salud-publica

6. Bases generales de colaboración que en el marco de la Ley de Seguridad Nacional celebran la Secretaría de Gobernación y la Secretaría de Salud. México: Diario Oficial de la Federación. 2013 May 05.

7. Ochoa-Carrera LA. Traslado de materiales biológicos valiosos a las nuevas instalaciones del Laboratorio Nacional de Referencia de México, Instituto de Diagnóstico y Referencia Epidemiológicos (InDRE) [Tesis de Maestría en Gestión de la Salud]. México: Universidad del Valle de México; 2014

8. Chávez-Briseño JJH. La comunicación humana como especialidad médica. Una visión al pasado, presente y futuro. Rev Mex AMCAOF. 2012;1:41-45.

9. Palabras de la Secretaria de Salud, Mercedes Juan, durante la celebración del Día Mundial de la Salud, marco en el cual se inauguró el Instituto de Diagnóstico y Referencia Epidemiológicos (InDRE). México: Secretaría de Salud, 2019. Available at: http://portal.salud.gob.mx/redirector?tipo=0\&n_seccion=Boletines\&seccion=2014-04-07_6882.html 
10. Barrera-Badillo G, Ramírez-González E, Aparicio-Antonio R, Núñez-García $T$, Arellano-Suarez $D$, Alcántara-Pérez $P$, et al. Notes from the field: Highly pathogenic avian influenza $A(H 7 N 3)$ virus infection in two poultry workers-Jalisco, Mexico. MMWR Morb Mortal Wkly Rep. 2012;61:726-727.

11. Garay-Morán C, Román-Pedroza JF, López-Martínez I, Rodríguez-Martínez JC, Ruiz-Matus C, Kuri-Morales P, et al. Clinical and epidemiological characterization of chikungunya fever in Mexico. Rev Panam Salud Publica. 2017:41:E58

12. Jiménez-Corona ME, De la Garza-Barroso AL, Rodríguez-Martínez JC, Luna-Guzmán NI, Ruiz-Matus C, Díaz-Quiñonez JA, et al. Clinical and epidemiological characterization of laboratory-confirmed autochthonous cases of Zika virus disease in Mexico. PLoS Curr. 2016:15:8.

13. González-Durán E, Vázquez-Pichardo M, Torres-Flores JM, Garcés-Ayala F, Méndez-Tenorio A, Curiel-Quesada E, et al. Genotypic variability analysis of DENV-1 in Mexico reveals the presence of a novel Mexican lineage. Arch Virol. 2018;163:1643-1647.

14. Vázquez-Pérez JA, Ramírez-González JE, Moreno-Valencia Y, Hernández-Hernández VA, Romero-Espinoza JA, Castillejos-López M, et al. EV-D68 infection in children with asthma exacerbation and pneumonia in Mexico City during 2014 autumn. Influenza Other Respir Viruses. 2016;10:154-160.

15. Kuri-Morales P, Correa-Morales F, González-Acosta C, Sánchez-Tejeda G, Dávalos-Becerril E, Juárez-Franco $F$, et al. First report of Stegomyia aegypti (=Aedes aegypti) in Mexico City, Mexico. Med Vet Entomol. 2017;31:240-242.

16. Dávalos-Becerril E, Correa-Morales F, González-Acosta C, Santos-Luna R, Peralta-Rodríguez J, Pérez-Rentería C, et al. Urban and semiurban mosquitoes of Mexico City: A risk for endemic mosquito-borne disease transmission. PLoS One. 2019;14:E0212987.

17. Díaz-Quiñonez A, Hernández-Monroy I, Montes-Colima N, Moreno-Pérez, A Galicia-Nicolás A, Martínez-Rojano H, et al. Outbreak of Vibrio cholerae serogroup 01, serotype Ogawa, biotype El Tor strain-La Huasteca Region, Mexico, 2013. MMWR Morb Mortal Wkly Rep. 2014;63:552-553.
18. Forbes reconoce a investigadoras por aportes en beneficio de la salud. Forbes México. 2019 Jun 18.

19. Ramírez-Hernández JA, Guzmán-Bracho C, Rodríguez-Pérez ME, Viesca-Treviño C, Díaz-Quiñonez JA. Desde el ISET al InDRE. III. Instituto de Salubridad y Enfermedades Tropicales: Crisis y renovación, 19651989. Gac Med Mex. 2019;155:641-646.

20. World Health Organization [website]. WHO TB Supranational Reference Laboratory Network. Suiza: WHO; 2019. Available at: https://www.who. int/tb/areas-of-work/laboratory/srl-network/en/

21. Fortalecimiento de la Red de Laboratorios de Tuberculosis en la Región de las Américas. Perú: Organismo Andino de Salud-Convenio Hipólito Unanue; 2019.

22. Embajadora Roberta Jacobson dona equipo médico. Embajada y Consulados de Estados Unidos en México; 2017. Available at: https://www. who.int/tb/areas-of-work/laboratory/srl-network/en/

23. Global Health Security Initiative [sitio web]. Canadá: GHSI; 2019.

24. World Health Organization [sitio web]. WHO Collaborating Centre for Training on Malaria Microscopy Diagnosis. Suiza: WHO; 2019.

25. World Health Organization [website]. WHO Collaborating Center on Laboratory Biosafety. Suiza: WHO; 2017.

26. World Health Organization [website]. WHO Collaborating Centre for Arboviruses. Switzerland: WHO; 2019. Available at: http://apps.who.int/ whocc/Detail.aspx?cc_ref=MEX-31

27. World Health Organization [website]. WHO Collaborating Centre on Laboratory Quality Management. Switzerland: WHO; 2018. Available at: http://apps.who.int/whocc/Detail.aspx?cc_ref=MEX-34\&cc_code=mex

28. World Health Organization [website]. WHO Collaborating Centres. Global database Mexico. Switzerland: WHO; 2019. Available at: http://apps.who. int/whocc/List.aspx?cc_code=MEX

29. Díaz-Quiñonez JA. Emergence of novel coronavirus SARS-CoV2 in China and the response in Mexico. Gac Med Mex. 2020;156(2):91193. DOI:10.24875/GMM.M20000345 